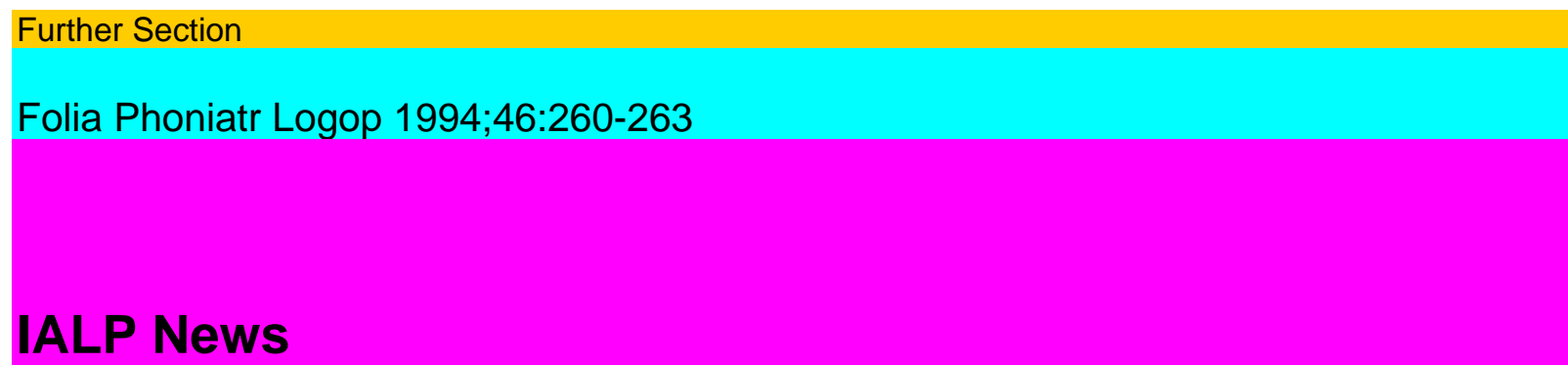

IALP Informative and consultative status (category B) with N EWS UNESCO, UNICEF, WHO, ECOSOC and CIOMS

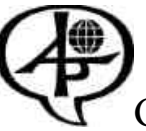

Present

Göteborg, August 21,1994

Board: Sr. M. de Montfort, President; Dr. A. Mul-ler, Past President; Prof. N. Kotby, Treasurer, President-Elect; Dr. E. Söderpalm, General Secretary.

Dr. B. Fex, Prof. H. Gregory, Prof. T. Hacki, Prof. J. Hirose, Prof. J. Hirschberg, Prof. R. Lesser, Prof. A. Pruszewicz, Prof. O. Schindler, Prof. H. Schutte, Prof. F. Sram and Dr. W. Wellens.

Committee Chairs: Mr. D. Brett, Prof. K. Butler, Prof. B. Fritzell.

Apologies

Mrs. M. Gordon and Prof. H. Oyer.

/. Welcome

Sr. Marie, President, welcomed the Board Members and the Committee Chairs and expressed satisfaction at the number of Board Members in attendance.

2. Application for Affiliation of SocietiesIt was decided to grant affiliation to

(a) The Japanese Speech-Language-Hearing Association,

(b)The Japanese Association of Speech Therapists JAST,

The Icelandic Association of Speech Therapists, and

The Polish Association of Speech Therapists PAST.

3. Membership

Senior Membership. No application for Senior membership had been received. Honorary

Membership.

It was agreed to propose Dr. Andre Muller as an honorary member. Decision will be taken by the General Assembly in 1995.

4. By-Laws and General Regulations

(a) Approval. The By-Laws agreed upon by the Board in 1993 will be published in IALP News'. Delegates will receive copies of the By-Laws through their Affiliated Societies. Individual Members and Dele-

gates will be informed via IALP News' and Affiliated Societies that all proposed amendments and issues to be raised regarding the By-Laws must reach the Board in writing before June 1995. The new document 'General Regulations' comprises 'Rules and Regulations', 'Rules and Regulations for Committees of IALP' and 'Rules and Regulations for Congress Organisers' approved by the Board in 1993. It was decided to present the By-Laws as the first item to the General Assembly in 1995 for immediate approval.

(b) Registration of IALP. It was decided to put IALP down for legal registration according to civil law in a country, hereby avoiding financial responsibility for any individual Board Member. 
5. Voting Procedures at General Assembly in CairoIndividual members unable to attend the GA can

apply in writing and will then receive voting material for postal voting prior to the congress. A notice will be placed in 'IALP News' with the By-Laws. Individual members attending the congress will be identified from the list of paid-up individual members and issued with voting cards before entering the GA room. Delegates nominated by the affiliated societies must vote on site. Voting cards will be issued also to Delegates in the same manner as with individual members. A counting committee will be appointed. It was agreed to recommend Dr. Hirose as Treasurer 1995-1998 and the General Secretary for a second term 1995-1998 and as PresidentElect from 1995.

6. Guidelines for Initial Education in LogopedicsThe Guidelines (third draft) was published in Folia

Phoniatrica et Logopedica 1994; 46:48-55 with an invitation for comments. Five replies were received; these comments are included in the fourth draft presented at the Board meeting. The comments were generally very positive. Communication Therapists International (UK), however, expressed concern about presenting 'guidelines' that might not help in the development of the most appropriate training programme in countries without established programmes. The Board's view was that many countries have asked not only for 'guidelines' but for 'standards' and that the main objective is to provide guidelines for those who

have already made the decision to develop programmes not to impose standards without regard for cultural and linguistic differences. It was decided to proceed slowly with a limited target as a first step. The section 6.1 (third draft) about IALP recognition of programmes' had been omitted in the fourth draft because of objections and this was supported by the Board. Further comments on the fourth draft should be sent before April 30, 1995 to Prof. Lesser, who will produce draft five for final discussion in Cairo.

7. Folia Phoniatrica et Logopedica

It was agreed that editorial problems of the IALP journal have to be solved separately from the issue of the Publisher. Tenders from the firms Karger and Whurr were compared. The Board discussed whether tradition and quality should be valued so highly as to stay with Karger or whether the favourable economical offer made by Whurr Company should lead to a change of publisher. After voting it was decided against a change of publisher (10 votes against and 5 for). It was decided that a committee should draw up rules and regulations for the organisation of the journal. Members: Ruth Lesser, chair, Björn Fritzell and Hen-ning Karlstad. It was further decided to set up an ad hoc editorial committee to look into the reviewing procedures, set terms for the editorial board and regulate relations with the publisher. Editorial committee: Members: Kay Butler, chair, Hugo Gregory, Nasser Kotby and Harm Schutte.

8. IALP (Committees) as Co-Sponsor of MeetingsThe issue of IALP supporting and/or sponsoring meetings was discussed. It was agreed that meetings can be organised in co-operation, but IALP cannot take on any financial commitment.

9. Committee Reports

History Committee. The third edition of the 'IALP History' was presented to the Board. In spite of the financial difficulties mentioned at the BM last year it has been possible to publish the new edition thanks to the efforts made by Prof. Perelló and Dr. Schindler.

Augmentative Committee. A business meeting will be held on October 8th in Maastricht on AAC in developing countries. 
Applied Audiology Committee. The committee has completed the work on the curriculum for the training of an Audiology Assistant and the programme is now placed in Thailand with Dr. Prasansuk, chair of the Department of Otorhinolaryngology at a hospital in Bangkok. The committee is planning for the Audiology Seminar in Cairo in 1995 and for the special issue of Folia Phoniatrica et Logopedica to appear in 1996.

Child Language Committee. A meeting is scheduled for Cairo and two proposals have been submitted: (1) A 3-hour symposium on 'Childhood Language Disorders: Research and Practice' and (2) a one and a half-hour seminar on 'Language Learning and Language Disorders in Culturally Diverse Contexts'.

Cleft Palate Committee. The final version of the protocol for evaluation of patients with velopharyngeal insufficiency is now available. Plans for the future work of the committee include elaboration of the basic principles for therapy of velopharyngeal insufficiency. A business meeting is planned for Cairo.

if) Education Committees. Logopedics: A further draft of the 'Guidelines' discussed at an extended committee meeting last year is anticipated. The committee is planning for two special sessions in Cairo (1) dealing with the IALP Guidelines and (2) dealing with speciality recognition. Phoniatrics: The courses planned in the main areas of phoniatrics to be taken by people wishing to achieve a IALP fellowship in phoniatrics have unfortunately been postponed due to the small number of applicants. Applications still arrive from all over the world.

(g) Fluency Committee. The chairman reported the death of Prof. Dean Williams, who has been a member of the committee since 1983. He was recognized among other things for directing many doctoral dissertations on stuttering. The committee is currently planning for a workshop at the Cairo Congress on procedures for modifying speech in people who stutter.

(h) School Committee. The committee organised a meeting and a workshop held in Newcastle, July 10-14 this year on 'Issues Facing Logopedics in the Primary School Setting'. The committee is planning for a session to be held in 1995 at the Cairo Congress.

10. New Committee Chair Persons

Dr. Don Cooper, USA, of the History Committee. Prof. Schutte was appointed new chairman of the Voice Committee. Appreciation of Prof. Hirano's work on the Committee was expressed.

11. Working Group for Underserved AreasName. It was decided by the Board upon suggestions from the group that it will be called 'The WorkingGroup for Human Communication Disorders in Underserved Areas'.

Mandate. The mandate as given by the Board in 1995 should be introduced with the following sentence at the beginning: 'General objective: To identify the needs and establish basic elementary services in the

261

domain of communicative disorders in underserved areas.'

Priorities. (1) The third world (Africa 1994-1998); (2) areas with some services but still underserved; (3) areas with generally good services but with under-served areas (big cities). Funding. The WG itself will be active in fund raising and letters seeking funding shall be signed by the IALP President. A symposium is scheduled at the Cairo Congress in 1995.

12. IALP NGO to UN

Dr. Steve Rosenbaum, New York, has accepted to serve as IALP's NGO representative to the United Nations.

13. Finances 
The financial situation in August 1994 is stable but does not allow for very ambitious goals. The income is derived from (1) fees from affiliated societies (no increase since 1993), (2) fees from individual members (20 SF per year), (3) interest from Reserve Fund, (4) Congress profits. Comparison between July 1st 1993 and 1994

Board Expenses are basically postage and small travel support. Only 15 Affiliated Societies have paid for 1994 and some of them have earlier debts and risk being expelled from IALP. A letter will be sent from the Treasury to the non-paying societies informing them that they will not be entitled to delegates nor will their members get reduced congress fees unless the societies pay their fees.

\section{The Cairo Congress}

The Congress will take place on August 6-10, 1995 at Cairo International Convention Centre. The second announcement will be distributed in December. November 1st is the deadline for Abstracts. The basic congress fee (for IM 350 US\$ before February) includes bus transport from airport, shuttle buses between convention centre and downtown hotels, social events, four lunches, two dinners and coffees. The Package deal (560 US \$ will also include three evening events

including the banquet and the proceedings. A half-day tour to the Egyptian Museum and Saqqara will take place on Tuesday.

15. The Haifa Conference, August 1-4, 1995Further information on the International Symposium on Communication Disorders in Bilingual Populations is available from the Organisation Committee, PO Box 9095, Ramat Efal 52190 (Israel).

\section{Correspondence}

An invitation to have a representative join the Board of Directors of the World Voice Consortium has been received. It was proposed that further discussions about goals and by-laws could take place at an invited meeting in Cairo, as there are at present several voice associations. Meeting in Mexico City on Communication Disorders. In a letter Dr. Martha Tarasco is seeking IALP co-operation for a Panamerican Phoniatry meeting. It was decided that the meeting could be held in co-operation with IALP preferably early in 1996.

Hearing International. IALP was invited to become a member of Hearing International last year. This invitation was accepted with the understanding that it bore no financial commitment. Due to the costs involved it was agreed to decline an invitation to send a representative of IALP to attend the Executive Board meeting and the first General Assembly of Hearing International to be held in Thailand.

17. Further Proposals

IALP Archive. At present, IALP documents are not collected in a systematic way. It was therefore agreed that basic documents should be moved from one President to his/her successor. The Congress in Amsterdam in 1998. The congress will take place on August 21-25, 1998. Early detection of speech and language disorders has been suggested for one of the plenary sessions. Postgraduate Courses. Prof. Sram distributed information regarding a postgraduate Phoniatric Centre in Prague and courses available at this centre.

18. Next Board Meeting in 1995

The Board will meet on Sunday, August 6, 1995.

Dublin and Göteborg, September 1994

Sr. Marie de Montfort Ewa Söderpalm

President General Secretary 
262

IALP News

IALP School Committee Holds Workshop in Newcastle, England

The School Committee held a workshop on July 10-13, 1994 in Newcastle, England. The topic of the meeting, which was held at the University of Newcastle upon Tyne, was 'The Issues Facing Logopedists (Speech and Language Pathologists/Therapists) in the Primary School Setting'.

The workshop opened on July 11 with welcoming speeches by Professor Ruth Lesser, Head of the University's Department of Speech; Sister Marie de Montfort, IALP President, and Committee Chair Richard Brett. Four main reports were presented on the opening day: 'New Directions in Language Therapy' by Sister Marie de Montfort; 'The Role of Logopedists Working in the Classroom' by Frances Block, Northwestern University, USA; 'Parent Involvement' by Leslie Atkinson, UK, and 'The Training of Teachers of Language-Impaired Children' by Jane Sadler, University of Newcastle. During the afternoon a visit was made to the Percy Hedley School for children with severe language impairment. Program participants had an opportunity to view the children in their classrooms.

On the second day of the workshop Professor Walter Elstner from Austria, former head of the School Committee, chaired the reports from individual countries, including Japan, China, Australia, Israel, USA, Switzerland, Netherlands, Austria, France, Germany, Malta, United Kingdom and Ireland. A visit to Durham was included on the second day.

On the final day of the workshop a round table discussion was conducted by Kay Mogford Bevan, UK, and was entitled 'The Differing Roles and Responsibilities of Professionals from Health and Education Working with Language-Impaired School Age Children'. Following the presentations by the seven speakers workshop participants raised questions regarding the different roles of health and education in the UK. The workshop concluded with group discussions on three topics:

'Effective Language Therapy in the Education Setting',

'Effective Parent Involvement', and

'Effective collaboration between Teachers'.

The success ofthis workshop, attended by approximately 25 professionals, was due to the organizational skills of Jane Sadler who was in charge of local arrangements.

Committee members decided to hold the next Committee workshop on August 5, 1995 at the time of the IALP Congress in Cairo, Egypt. The topic ofthis workshop will feature the adolescent in the school setting.

Details of this workshop will be announced in the near future. Information regarding the future workshop in Cairo and the past workshop in Newcastle may be obtained from the School Committee Chair:

Richard J. Brett,

771 Linden Avenue, Apartment 1W,

Waukegan, IL 60085 (USA)

School Fax: 708-360-5399

Akademische Feier aus Anlass des 70. Geburtstages von Gerhard Kittel

Internationales Symposion: «Zur Differentialdiagnose von Stimmerkrankungen», Erlangen, 4.3.95 
Für: HNO-Ärzte aus Praxis und Klinik. Thema: Diagnose und Therapie funktioneller und organischer Stimmstörungen. Auskunft und Voranmeldung:

Frau Priv. Doz. Dr. U. Pröschel Abteilung Phoniatrie und Pädaudiologie Bohlenplatz 21, D91054 Erlangen (Deutschland)

Tel. (09131) 853813 bzw. 853146 Fax (09131) 859272

Teilnahmegebühr: Keine.

Mittagessen nach dem Symposium: DM 50,00.

7. Erlanger Block-Kurs für Phoniatrie und Pädaudiologie

1.3-3.3.95, Leitung: Prof. Dr. Dr. U. Eysholdt

Für: HNO-Ärzte aus Praxis und Klinik.

Thema: Sprech-, Sprach- und Redeflussstörungen; Kindliche Hörstörungen; Funktionelle und organische Stimmstörungen (mit praktischen Übungen).

Teilnehmerzahl: Begrenzt, Berücksichtigung nach der Reihenfolge der Anmeldungen.

Teilnahmegebühr: DM 500,- inklusive Mittagessen und Gemeinschaftsabend zuzügl. (optional)

DM 200,- für praktische Übungen (für Teilnehmer aus den neuen Bundesländem 20\%

Ermässigung).

Auskunft und Voranmeldung:

Frau Priv. Doz. Dr. U. Pröschel Abteilung Phoniatrie und Pädaudiologie Bohlenplatz 21, D91054 Erlangen (Deutschland)

Tel. (09131) 853813 bzw. 853146 Fax(09131) 859272

263 